\title{
ANALISIS KEMAMPUAN PEMBUKTIAN MATEMATIS PADA MATAKULIAH ANALISIS REAL BERDASARKAN ADVERSITY QUOTIENT
}

\author{
${ }^{1}$ Era Dewi Kartika, ${ }^{2}$ Nok Izatul Yazidah \\ 1,2Jurusan Pendidikan Matematika FPIEK IKIP Budi Utomo Malang, Jl. Citandui no 46, Telp (0341) 323214, \\ Indonesia \\ e-mail: erfolgera@gmail.com
}

\begin{abstract}
Abstrak
Tujuan dari penelitian ini adalah untuk mendeskripsikan kemampuan pembuktian matematis pada matakuliah analisis real berdasarkan Adversity Quotient (AQ). Jenis penelitian ini merupakan penelitian kualitatif deskriptif. Subjek penelitian terdiri dari 6 orang yang terdiri dari Quitter, Camper, dan Climber. Analisis data kualitatif terdiri dari (a) mengolah dan mempersiapkan data, (b) membaca keseluruhan data, (c) mengkoding data, serta (d) menarasikan deskripsi data yang dianalisis. Hasil penelitian menunjukkan bahwa lebih dari 50\% mahasiswa yang telah mengikuti matakuliah analisis real berada pada level Camper berdasarkan AQ. Mahasiswa Camper lebih mampu menyusun pembuktian langsung dibandingkan mahasiswa Quitter dan Climber. Mahasiswa pada ketiga level AQ belum mampu menyebutkan definisi bilangan rasional dengan benar dan lengkap. Masih terdapat mahasiswa yang menggunakan pengambilan contoh untuk pembuktian langsung.
\end{abstract}

Kata kunci: kemampuan pembuktian matematis, analisis real, adversity quotient

\begin{abstract}
The purpose of this research is to describe the mathematical proof ability in real analysis subjects based on Adversity Quotient (AQ). This type of research is descriptive qualitative research. The research subjects consisted of 6 people consisting of Quitter, Camper, and Climber. Qualitative data analysis consists of (a) processing and preparing data, (b) reading the entire data, (c) coding the data, and (d) narrating the description of the data being analyzed. The results of the research show that more than $50 \%$ of students who have attended real analysis courses are at the Camper level based on AQ. Camper students are better able to arrange direct proof than Quitter and Climber students. Students at all three levels of AQ have not been able to properly and completely define the definition of rational numbers. There are still students who use example for direct proof.
\end{abstract}

Keywords: mathematical proof ability, real analysis, adversity quotient

\section{PENDAHULUAN}

Matematika merupakan ilmu yang bersifat deduktif aksiomatik yang artinya struktur pada matematika diawali dengan istilah yang tidak terdefinisi, lalu selanjutnya istilah yang didefiniskian, dan kemudian disusun sebuah pernyataan yang disebut aksioma dan postulat yang nantinya akan digunakan untuk menyusun teorema-teorema yang nantinya akan dibuktikan dengan proses deduktif sehingga memperoleh kebenaran yang berlaku secara umum dalam sistemnya. Dalam pembuktian teorema-teorema tersebut biasanya menggunakan pembuktian tak langsung maupun dengan pembuktian langsung. Bentuk pembuktian tidak langsung adalah pembuktian dengan cara kontradiksi dari apa yang akan kita buktikan, sedangkan bentuk pembuktian langsung diantaranya adalah pembuktian dengan eliminasi kasus, dan pembuktian denga ekuivalensi (Sadikin: 2009). Lebih lanjut Bell 
(1976) mendefinisikan bukti sebagai skema aksioma, konsep dasar dan teorema yang diperoleh melalui metode deduktif.

Pembuktian bagi kalangan matematikawan memiliki peranan yang sangat penting, Mengapa? Karena, pembuktian sebagai suatu metode meyakinkan yang digunakan untuk menguji pengetahuan. Bagi mahasiswa matematika bukti itu bisa diibaratkan seperti makanan sehari-hari, dimana hampir setiap mata kuliah mereka bekerja dengan menggunakan bukti matematika. Namun demikian kadang istilah bukti yang dipahami oleh setiap mahasiswa berbeda dengan tafsiran yang dimiliki oleh dosen, demikian pula dengan tafsiran yang dimiliki dosen bisa jadi berbeda dengan dosen yang lain. Pembuktian matematika memungkinkan penciptaan argumen yang nantinya dapat diterima pada saat mempresentasikannya di depan kelas (Stylianides, 2007). Lebih lanjut Tall (1989) menjelaskan bahwa dalam kasus matematika perguruan tinggi di seluruh dunia, konstruksi dan pemahaman mahasiswa terhadap pembuktian matematika harus lebih ditekankan. Terutama bagi calon guru matematika yang diharapkan untuk mengajar pembuktian matematika untuk generasi berikutnya.

NCTM (2000) menyatakan bahwa pembuktian matematika merupakan salah satu aspek yang harus mendapatkan perhatian lebih utama dalam pembelajaran matematika. Menurut Educational Development Center (2003) menyatakan bahwa pembuktian matematis antara lain: (a) menyusun suatu fakta dengan pasti; (b) mendapatkan pemahaman; (c) menyampaikan gagasan kepada orang lain; (d) tantangan; (e) membuat sesuatu mudah difahami; (f) mengkonstruksi teori matematika. Metode pembuktian diperlukan untuk meyakinkan kebenaran pernyataan atau teorema pada umumnya berbentuk implikasi atau biimplikasi.

Salah satu matakuliah yang didominasi pembuktian matematis adalah analisis real. Pada matakuliah ini lebih banyak difokuskan pada kemampuan untuk membuktikan suatu masalah dengan landasan yang kuat seperti berdasar pada aksioma, postulat, sifat, lema, teorema dan lain sebagainya. Analisis real dikenal juga dengan "the body of mathematics". Menurut Guswanto (2006) menyatakan bahwa analisis real merupakan alat yang esensial, baik didalam berbagai cabang dari matematika maupun bidang ilmu-ilmu lain seperti fisika, kimia, dan ekonomi. Melalui matakuliah ini mahasiswa berlatih untuk menyimpulkan bahwa suatu pernyataan itu benar, menjelaskan mengapa suatu pernyataan itu benar, mengkomunikasikan pengetahuan matematika, dan menuliskannya dalam bahasa logis dan sistematis. Kemampuan tersebut dapat ditingkatkan melalui kegiatan pembuktian. 
Berdasarkan hasil observasi yang dilakukan pada mahasiswa diperoleh fakta bahwa mahasiswa masih merasa kesulitan dalam mebuktikan teorema-teorema yang ada di dalam buku analisis real, mahasiswa masih bingung dalam menyusun rencana pembuktian teoremateorema tersebut, ketika mahasiswa diberikan contoh pembuktian mahasiswa merasa sudah mampu menyelesaikannya namun setelah diberikan pembuktian yang berbeda dan tanpa bantuan dosen mahasiswa merasa kebingungan kembali. Dalam membuktikan teoremateorema tersebut peneliti melihat beragam cara yang dilakukan mahasiswa dalam penyelesaian pembuktian analisis real tersebut. Untuk lebih menspesifikasikan hasil analisis peneliti pada kemampuan pembutian matematis mahasiswa berdasarkan Adversity Quotient (AQ). Stoltz (2007) menyatakan bahwa Adversity Quotient sebagai kecerdasan seseorang untuk bertahan dalam menghadapi dan mengatasi kesulitan. Dalam penelitian ini yang maksud kesulitan adalah kesulitan dalam pembutian matematis pada mata kuliah analisis real. Sehingga tujuan dari penelitian ini adalah untuk mendeskripsikan kemampuan pembuktian matematis pada matakuliah analisis real berdasarkan Adversity Quotient (AQ).

\section{METODE PENELITIAN}

Penelitian ini dilaksanakan di IKIP Budi Utomo Malang pada matakuliah Analisis Real yang diajarkan pada semester 5. Jenis penelitian ini merupakan penelitian kualitatif deskriptif. Subjek penelitian ini merupakan mahasiswa Pendidikan Matemtika IKIP Budi Utomo Malang yang dipilih secara acak. Subjek penelitian terdiri dari 6 orang yang terdiri dari Quitter, Camper, dan Climber. Pertimbangan pemilihan subjek juga didasarkan pada hasil tes AQ dan juga kemampuan komunikasi yang baik yang dibutuhkan dalam melakukan tahap wawancara.

Instrumen yang dibutuhkan dalam penelitian ini adalah lembar soal tes AQ, dan lembar soal Analisis Real. Lembar soal AQ ditujukan untuk mengelompokan mahasiswa menjadi Quitter, Camper, dan Climber. Soal tes analisis real digunakan untuk mengetahui kemampuan pembuktian matematis mahasiswa.

Analisis data kualitatif mengacu pada Creswell (2009) yang terdiri dari (a) mengolah dan mempersiapkan data yang akan dianalisis, (b) Membaca keseluruhan data, (c) mengkoding data dan menerapkan proses koding untuk mendeskripsikan data yang akan dianalisis, serta (d) menarasikan deskripsi data yang dianalisis. 


\section{HASIL DAN PEMBAHASAN}

Kemampuan pembuktian matematis meliputi kemampuan menyusun pembuktian dan kemampuan memvalidasi bentuk pembuktian (Perbowo, 2017). Pada penelitian ini hanya akan diamati kemampuan menyusun pembuktian. Sedangkan kemampuan mahasiswa yang diamati pada penelitian ini hanya kemampuan dalam pembuktian matematis secara langsung. Mahasiswa yang telah mengikuti matakuliah Analisis Real mengisi lembar soal tes AQ yang selanjutnya dipilih masing-masing dua mahasiswa untuk Quitter, Camper, dan Climber.

Sebanyak 20 mahasiswa yang telah mengisi lembar soal tes AQ, diperoleh 11 mahasiswa Camper, 4 mahasiswa Climber, dan 5 mahasiswa Quitter. Hal ini menunjukkan bahwa lebih dari 50\% mahasiswa berada di level Camper.

Pada lembar soal analisis real, dua subyek Quitter menunjukkan hasil bahwa tidak mampu menyelesaikan pembuktian dengan benar. Subyek 1 Quitter tidak menuliskan definisi bilangan rasional, menggunakan cara mengambil contoh untuk membuktikan dan tanpa ada pernyataan kebenaran dari pembuktian yang telah disusun. Subyek 2 Quitter sudah terdapat pernyataan kebenaran dari pembuktian yang telah disusun namun masih menggunakan pengambilan contoh untuk pembuktian langsung dan tanpa adanya definisi dari bilangan rasional.

Subyek 1 dan subyek 2 Camper dapat mendefinisikan bilangan rasional dengan benar walaupun kurang lengkap. Dua subyek Camper dapat menyusun pembuktian langsung dengan benar, meskipun subyek 1 tidak dapat menyatakan kebenaran dari pembuktian yang telah disusun.

Berbeda dengan dua subyek Camper yang dapat menyelesaikan pembuktian matematis secara langsung dengan benar, dua subyek Climber yang terpilih tidak dapat menyelesaikan pembuktian dengan utuh dan benar. Subyek 1 Climber dapat mendefinisikan bilangan rasional namun tidak lengkap. Pada susunan pembuktian subyek 1 juga terdapat kesalahan perhitungan penjumlahan dua bilangan rasional. Sedangkan pada subyek 2 Climber susunan pembuktian mempunyai tipe yang sama dengan subyek 2 Quitter.

Wawancara yang dilakukan pada setiap subyek menunjukkan bahwa 2 subyek Quitter belum memahami susunan pembuktian langsung dan tidak dapat menyebutkan definisi bilangan rasional. Dua subyek Camper dapat menjelaskan seluruh susunan pembuktian dengan lancar. Sedangkan dua subyek Climber, untuk subyek 1 dapat memberikan penjelasan kesalahannya pada saat perhitungan kemudian dapat menyatakan kebenaran dari pembuktian. 
Subyek 2 Climber dapat menyebutkan definisi bilangan rasional dengan benar, namun masih kurang memahami susunan pembuktian secara langsung.

\section{SIMPULAN DAN SARAN}

Berdasarkan hasil penelitian dan pembahasan diatas dapat dikemukakan beberapa kesimpulan yaitu:

1. Lebih dari $50 \%$ mahasiswa yang telah mengikuti matakuliah analisis real berada pada level Camper berdasarkan AQ

2. Mahasiswa Camper lebih mampu menyusun pembuktian langsung dibandingkan mahasiswa Quitter dan Climber

3. Mahasiswa belum mampu menyebutkan definisi bilangan rasional dengan benar dan lengkap

4. Mahasiswa masih menggunakan pengambilan contoh untuk pembuktian langsung

5. Mahasiswa belum memberikan pernyataan kebenaran pada akhir pembuktian

Sedangkan saran untuk penelitian berikutnya adalah:

1. Perlu adanya pemantapan pemahaman penyusunan pembuktian langsung pada mahasiswa

2. Pengenalan metode pembuktian yang lain pada mahasiswa seperti kontraposisi, kontradiksi, induksi matematika dan counterexample

3. Perlu adanya penelitian lebih lanjut tentang faktor-faktor pemnghambat mahasiswa dalam penyusunan pembuktian matematis

4. Pemilihan model pembelajaran yang sesuai untuk memahamkan mahasiswa dalam penyususnan pembuktian matematis

\section{DAFTAR PUSTAKA}

Bell, A. (1976). A Study Of Pupils’ Proof-Explanations In Mathematical Situation. Educational Studies in Mathematics, 7, 23-40.

Creswell, J. W. (2009). Research Design: Qualitative, Quantitative, and Mixed Methods Approaches Third Edition. USA: Sage Publication.

NCTM. (2000). Principles and Standards for School Matematics. Reston, Virginia.

Perbowo, Krisna S. (2017). Pemetaan Kemampuan Pembuktian Matematis Sebagai Prasyarat Mata Kuliah Analisis Riil Mahasiswa Pendidikan Matematika. Jurnal Pendidikan Matematika KALAMATIKA Vol. 2 No. 1 April 2017 hal 81-90 
Stoltz, PG. (2007). Adversity Quotient: Mengubah Hambatan Menjadi Peluang (Terjemahan: T. Hermaya). Jakarta: Grasindo.

Stylianides, A. J. (2007). Proof And Proving In School Mathematics. Journal for Research in Mathematics Education, 38(3), 289-321.

Tall, D. (1989). The Nature Of Mathematical Proof. Mathematics Teaching,127, 28-32.

Sadikin, A. (2009). Pengantar logika matematika dan himpunan. Pontianak: STAIN Pontianak Press. 